\section{High Tunnel and Field Production of Organic Heirloom Tomatoes: Yield, Fruit Quality, Disease, and Microclimate}

\author{
Suzanne O'Connell ${ }^{1}$ \\ Department of Horticultural Science, North Carolina State University, \\ Kilgore Hall, Raleigh, NC 27695-7609
}

Cary Rivard ${ }^{2}$

Kansas State University, Olathe, KS 66061

\author{
Mary M. Peet ${ }^{3}$ \\ National Institute of Food and Agriculture, U.S. Department of Agriculture, \\ Washington, DC 20024-2220 \\ Chris Harlow ${ }^{4}$ \\ Department of Horticultural Science, North Carolina State University, \\ Kilgore Hall, Raleigh, NC 27695-7609 \\ Frank Louws ${ }^{5,6}$ \\ North Carolina State University, 2411 Gardner Hall, Campus Box 7616, \\ Raleigh, NC 27695-7616
}

Additional index words. Solanum lycopersicum, greenhouse, season extension, plasticulture, hoop house, local markets, IPM

\begin{abstract}
Organic and heirloom tomatoes are high-value products with growing demand but there are many challenges to successful cultivation. A systems comparison study was carried out to evaluate the production of the popular heirloom tomato 'Cherokee Purple' (Solanum lycopersicum L.) under high tunnel and open field systems in North Carolina from 2007 to 2008. Management of the high tunnel (i.e., temperature and irrigation), weather events as well as pest and disease pressure influenced crop quality and yield. The high tunnel and field systems achieved similar total yields $\left(100 \mathrm{t} \cdot \mathrm{ha}^{-1}\right)$ the first season but yields were $33 \%$ greater in the high tunnel system than the field system in the second year (100 t.ha $\mathrm{h}^{-1}$ and $67 \mathrm{t} \cdot \mathrm{ha}^{-1}$, respectively). Both years, the tomatoes were planted in high tunnels 1 month earlier and harvested 3 weeks earlier than the field. The accumulation of $\approx 1100$ growing degree-days (GDD) was required in both systems before $50 \%$ of the fruit was harvested. Fruit cracking, cat-facing, blossom-end rot, and insect damage were the major categories of defects in both systems. Incidence of both Tomato Spotted Wilt Virus (TSWV) and Gray Leaf Spot (GLS) were lower in the high tunnel compared with the field in 2007 and 2008, respectively. Results of this study suggest that with proper management techniques, high tunnels can optimize yields, increase fruit quality, and provide season extension opportunities for high-value horticultural crops.
\end{abstract}

Received for publication 2 Apr. 2012. Accepted for publication 12 June 2012.

We wish to thank Steve and Josh Moore, Carolyn Lowry, Ian Fiske, Thomas Rufty, Joy Smith, CEFS/NCDA staff, the NCSU Phytotron and Fox greenhouse staff, the NCSU Integrated Disease Management Lab, and many seasonal employees for their assistance. Fertilizers donations from Nutrimax, Inc., and Petrik, Inc. were greatly appreciated and funding by S-SARE \#LS06-193 $\&$ \#GS07-060 made this endeavor possible.

${ }^{1}$ Research Assistant.

${ }^{2}$ Assistant Professor of Horticulture, Forestry and Recreation.

${ }^{3}$ Division Director of Plant Production.

${ }^{4}$ Research Specialist.

${ }^{5}$ Professor of Plant Pathology.

${ }^{6}$ To whom reprint requests should be addressed; e-mail Frank_Louws@ncsu.edu. greater revenue compared with many other crops. This allows for a quick recovery of the initial investment and ongoing income to sustain management expenses. Capital investments in high tunnels can typically be recovered over 1 to 5 years (Blomgren and Frisch, 2007; Conner et al., 2010; Waterer, 2003).

A 2005-2007 survey of Midwest high tunnel growers reported that tomatoes were the most commonly grown high tunnel crop (Knewston et al., 2010) and trends in the fresh tomato market indicate increasing consumer demand for both organically grown and heirloom varieties (Calvin and Cook, 2005; Lucier, 2009; Lyson et al., 1995; Stevens-Garmon et al., 2007). Organic tomatoes often garner a $15 \%$ to $20 \%$ price premium over conventionally grown crops (Fernandez-Cornejo et al., 1994; Stevens-Garmon et al., 2007) and heirloom varieties are sold for up to $\$ 15.4 / \mathrm{kg}$ at specialty markets (Jordan, 2007).

Heirlooms are open-pollinated varieties that are valued for their unique colors, shapes, flavors, and legacies. Heirloom tomatoes typically lack shape uniformity and have thinner skins compared with more modern varieties, making them difficult to pack and transport over long distances. In addition, growing heirlooms can be challenging as a result of lack of disease resistance and lower yields compared with many modern varieties (Rivard and Louws, 2008). Despite the challenges in heirloom tomato production, customer demand for these varieties has increased over the last two decades, paralleling a rise in support for organic products and farmers' markets (Jordan, 2007).

Currently, the organic market represents $4 \%$ of the total food sales in the United States [Organic Trade Association (OTA), 2011)]. Both the organic market and farmers markets have exhibited strong positive growth trends over the last two decades. Even during the recent economic recession (2009-2010), the organic fruit and vegetable market gained an $11.8 \%$ increase in sales, which represents $\$ 1.1$ billion in new produce sales (OTA, 2011). Local and direct market sales outlets continue to expand. In the last 15 years, the number of farmers' markets has increased by more than $400 \%$ and North Carolina currently ranks as one of the top 10 states for total number of farmers markets in the United States (Agricultural Marketing Services, 2011).

High tunnel technology is best explored at a regional level as a result of the opportunities and limitations presented by the local climate. Research studies that explore horticultural production under high tunnels in the United States indicate a variety of positive benefits. More than 1 month of early-season extension was reported for high tunnel production in New Hampshire tomatoes (Wells, 1991) as well as Kansas and Utah strawberries (Fragaria ×ananassa) (Kadir et al., 2006; Rowley et al., 2010). In addition, Florida strawberry yields were $54 \%$ greater and marketable fruit weight $69 \%$ greater in high tunnels compared with the field (Salame-Donoso et al., 2010). Flower and fruit production were accelerated for Southern highbush blueberry 
(Vaccinium corymbosum L.) in Georgia; however, the lack of nighttime freeze protection in the spring made the crop vulnerable to fruit abortion (Ogden and van Iersel, 2009). Minnesota production of high tunnel raspberries (Rubus fruticosus) benefitted from greater yields and extended seasons (Yao and Rosen, 2011) as well as increased fruit quality and decreased disease incidence for raspberry in Michigan (Hanson et al., 2011).

Information regarding high tunnel production systems in the southeast region is very limited. Exploration of the use of high tunnel systems would help growers who supply a growing regional market and take advantage of a lengthy, subtropical growing season. Therefore, our study objectives included a replicated, systems-level comparison of organic heirloom tomato production under high tunnels and the open field in eastern North Carolina (USDA hardiness zone $7 \mathrm{~b}$ to 8a). Differences in crop yield and fruit quality were examined as well as microclimate and disease incidence.

\section{Materials and Methods}

Site background. The study was conducted at the Center for Environmental Farming Systems located in Goldsboro, NC (lat. $035^{\circ} 24^{\prime} 05^{\prime \prime} \mathrm{N}$, long. $078^{\circ} 01^{\prime} 52.6^{\prime \prime} \mathrm{W}$ ) during 2007 and 2008. Soils are categorized as a Wickham sandy loam. In 2006, the site was fumigated with methyl bromide to manage the federally listed noxious weed Commelina benghalensis L. and then planted with a succession of cool-season cover crops. There was no recent history of Solanaceae production at this site. All aspects of construction and agricultural production methods were performed under the guidelines of the USDA
National Organic Program (NOP) certification standards (7 U.S.C. § 6501) although the site was not certified as a result of the time limitations presented by the prior fumigation event. Therefore, this study is best categorized as "transitional to organic."

Experimental design. Two snow-arch design high tunnels $(29.3 \mathrm{~m} \times 9.1 \mathrm{~m} \times 3.7 \mathrm{~m})$ were constructed on site in 2007 (Atlas Greenhouses Inc., Alapaha, GA). High tunnel features included: bows every $1.2 \mathrm{~m}$, an inflated double polyethylene film roof ["K50 Clear (0.152 mm)"; Klerks Hyplast Inc., Chester, $\mathrm{SC}$, twin-wall polycarbonate end walls, and an automated "1.8 m Z-Lock drop-down curtain system." Doors built into the end walls were wide enough to allow the passage of a small tractor for tillage operations. Two equivalent field plots were established as controls, $15 \mathrm{~m}$ adjacent and parallel to each high tunnel (Fig. 1). The high tunnels were oriented east-west to be perpendicular to the prevailing winds at this site.

Treatments (growing system type) were replicated four times (two blocks per one high tunnel and two blocks per one corresponding field plot). Crop management and data collection were carried out by block. Experimental units in both the high tunnel and field system consisted of six plants per row. Rows were $3.7 \mathrm{~m}$ in length with plants set at $61 \mathrm{~cm}$ in-row spacing. Rows were $1.4 \mathrm{~m}$ apart, resulting in a planting density of 11,960 plants/ha $\left(0.84 \mathrm{~m}^{2} /\right.$ plant $)$. Blocks were rerandomized each year and unsampled guard rows were included on terminal ends of each high tunnel and field plot. The regionally popular, heirloom, indeterminate cultivar Cherokee Purple (Solanum lycopersicum L.) (Johnny's Selected Seeds, Winslow, ME) was used throughout this experiment.
Systems management. Cultural management practices specific to each system were followed in an effort to optimize system production capability. This approach allows for a more accurate comparison of two distinct growing systems, one that can capture the interactions unique to each farming system even if they cannot be singly reduced (Wilson and Morren, 1990). Planting dates in the high tunnel system were 20 Mar. 2007 and 18 Mar. 2008, whereas planting dates in the field were $\approx 1$ month later, 19 Apr. 2007 and 17 Apr. 2008 (after the threat of frost had passed). Because the high tunnel system was planted earlier, its growing season was $\approx 4$ weeks longer than the field treatment each year. Large sheets $(29.3 \mathrm{~m} \times 9.1 \mathrm{~m})$ of black polypropylene landscape fabric were secured with metal fabric pins and used as a weed barrier in both systems. Holes $(\approx 10.2 \mathrm{~cm} \times 10.2 \mathrm{~cm})$ were cut out of the fabric as required to accommodate the planting of each seedling. Hand weeding was carried out around the base of the plants as needed.

Irrigation was delivered through a single drip tape (per row) with emitters spaced

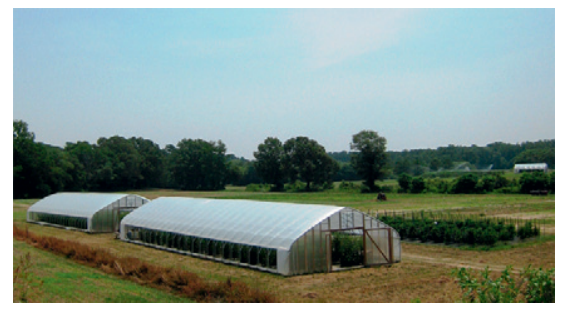

Fig. 1. Photograph of the two high tunnels $(29.3 \mathrm{~m}$ $\times 9.1 \mathrm{~m} \times 3.7 \mathrm{~m})$ and the adjacent field plots located at the Center for Environmental Farming Systems (CEFS) in Goldsboro, NC.

Table 1. Estimated nitrogen (N) contributions from organic fertilizers and amendments applied to high tunnel and field system, 2007 and 2008.

\begin{tabular}{|c|c|c|c|c|c|c|}
\hline System & Yr & Material & Application rate & $\begin{array}{l}\text { Cover crop shoot } \\
\text { biomass (dry wt) }\end{array}$ & $\begin{array}{c}\text { Percent } \mathrm{N} \\
\text { (estimated availability) }\end{array}$ & $\begin{array}{c}\text { Total } \mathrm{N} \\
\text { contribution }\end{array}$ \\
\hline \multirow[t]{7}{*}{ High tunnel } & 2007 & & & & & \\
\hline & & Compost $(2 \mathrm{~N}-0.9 \mathrm{P}-1.7 \mathrm{~K})$ & $22.6 \mathrm{t} \cdot \mathrm{ha}^{-1}$ & - & $2.2 \%(70 \%)^{\mathrm{z}}$ & $28 \mathrm{~kg} \mathrm{~N} / \mathrm{ha}$ \\
\hline & & Feathermeal $(12 \mathrm{~N}-0.4 \mathrm{P}-0 \mathrm{~K})$ & $101.7 \mathrm{~kg} \cdot \mathrm{ha}^{-1}$ & - & $12.0 \%(70 \%)^{\mathrm{y}}$ & $71 \mathrm{~kg} \mathrm{~N} / \mathrm{ha}$ \\
\hline & & Phytamin $801(6 \mathrm{~N}-0.4 \mathrm{P}-0.8 \mathrm{~K})^{\mathrm{w}}$ & - & - & $0.6 \%(100 \%)$ & $13 \mathrm{~kg} \mathrm{~N} / \mathrm{ha}$ \\
\hline & & & & & Total & $112 \mathrm{~kg} \mathrm{~N} / \mathrm{ha}$ \\
\hline & 2008 & $\begin{array}{l}\text { Cover crop: Secale cereal and } \\
\text { Vicia villosa }\end{array}$ & $\begin{array}{l}50.4 \mathrm{~kg} \cdot \mathrm{ha}^{-1} \text { and } \\
33.6 \mathrm{~kg} \cdot \mathrm{ha}^{-1}\end{array}$ & $\begin{array}{c}4202.5 \mathrm{~kg} \cdot \mathrm{ha}^{-1} \text { and } \\
368.8 \mathrm{~kg} \cdot \mathrm{ha}^{-1}\end{array}$ & $\begin{array}{l}4.0 \%(50 \%)^{\mathrm{x}} \text { and } \\
5.1 \%(50 \%)^{\mathrm{x}}\end{array}$ & $93 \mathrm{~kg} \mathrm{~N} / \mathrm{ha}$ \\
\hline & & Phytamin $801(6 \mathrm{~N}-0.4 \mathrm{P}-0.8 \mathrm{~K})^{\mathrm{w}}$ & - & - & $0.6 \%(100 \%)$ & $19 \mathrm{~kg} \mathrm{~N} / \mathrm{ha}$ \\
\hline
\end{tabular}

Field

2007

Compost $(2 \mathrm{~N}-0.9 \mathrm{P}-1.7 \mathrm{~K})$

Feathermeal (12N-0.4P-0K)

Phytamin $801(6 \mathrm{~N}-0.4 \mathrm{P}-0.8 \mathrm{~K})^{\mathrm{w}}$

$22.6 \mathrm{t} \cdot \mathrm{ha}^{-1}$

$101.7 \mathrm{~kg} \cdot \mathrm{ha}^{-1}$

2008

Cover crop: Secale cereal and
Vicia villosa

Feathermeal $(12 \mathrm{~N}-0.4 \mathrm{P}-0 \mathrm{~K})$

Phytamin $801(6 \mathrm{~N}-0.4 \mathrm{P}-0.8 \mathrm{~K})^{\mathrm{w}}$
$50.4 \mathrm{~kg} \cdot \mathrm{ha}^{-1}$ and $33.6 \mathrm{~kg} \cdot \mathrm{ha}^{-1}$ $58.9 \mathrm{~kg} \cdot \mathrm{ha}^{-1}$ -

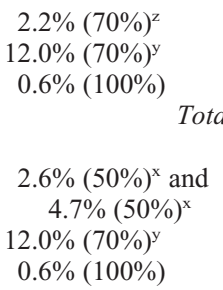

$2.6 \%(50 \%)^{\mathrm{x}}$ and $4.7 \%(50 \%)^{x}$

$12.0 \%(70 \%)^{y}$

$0.6 \%(100 \%)$$$
\text { - }
$$$$
809.1 \mathrm{~kg} \cdot \mathrm{ha}^{-1} \text { and }
$$$$
1781.1 \mathrm{~kg} \cdot \mathrm{ha}^{-1}
$$$$
\text { - }
$$

${ }^{2}$ Estimates of nitrogen availability coefficient based on NCDA\&CS Waste Analysis Report \#W07714 and Baldwin and Greenfield, 2006.

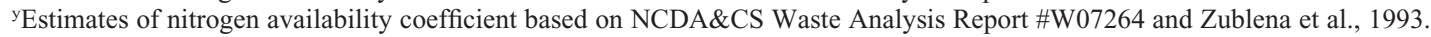

${ }^{\mathrm{x}}$ Estimates of nitrogen availability coefficient based on NCDA\&CS, Plant Tissue Analysis Reports \#P00880, \#P01101 and Baldwin and Creamer, 2006.

${ }^{\text {w}}$ Fertigation rates on different dates were dependent on the stage of crop growth. 
Table 2. Potassium (K) fertilizer applications to high tunnel and field system, 2007 and 2008.

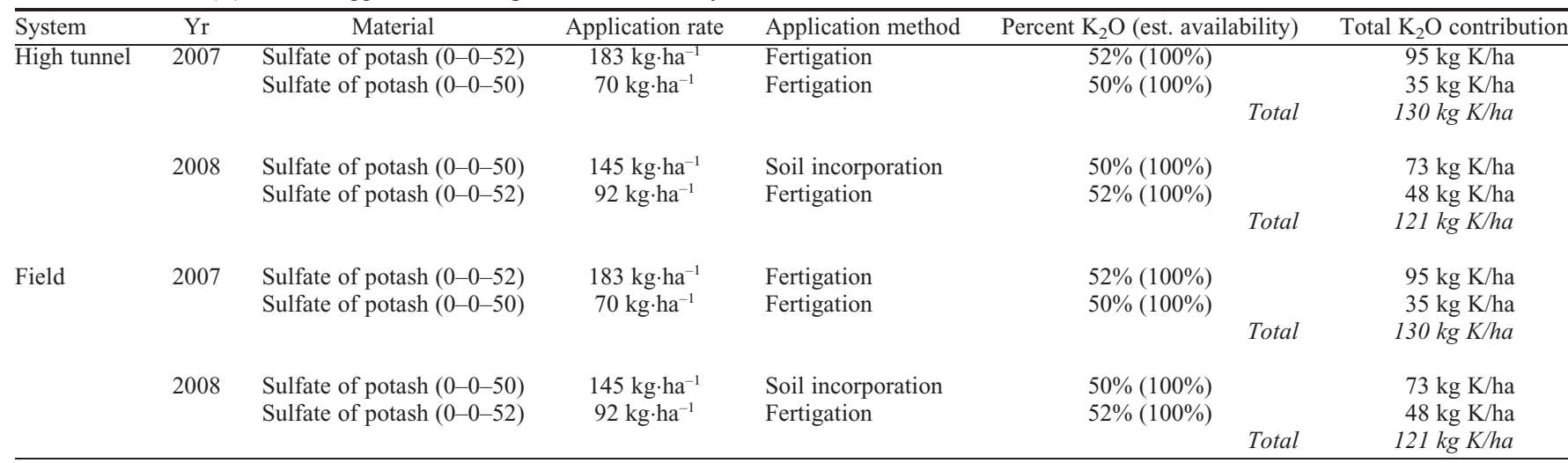

every $30.5 \mathrm{~cm}$ and a flow rate of $19 \mathrm{~L} \cdot \mathrm{h}^{-1}$ per $30.5 \mathrm{~m}$. Irrigation in the high tunnels and field system was administered equivalently with one exception; the field system did not receive irrigation for $24 \mathrm{~h}$ after substantial rainfall events $\left(1.25 \mathrm{~cm} \cdot \mathrm{d}^{-1}\right.$ or greater $)$. In 2007 , plants received a total of 30 to $90 \mathrm{~min}$ of irrigation (depending on crop growth stage) daily (0900 HR) using a mechanical water timer. In 2008, irrigation protocols were slightly modified. Plants received a total of 30 to 90 min of irrigation (depending on crop growth stage) twice daily (0900 HR and $1300 \mathrm{HR}$ ) using a mechanical water timer. Soil moisture conditions were monitored using automatic soil moisture probes (HOBO Micro Station \#H21-002 Data Logger; Onset Computer Corp., Bourne, MA; \#S-SMA-M005).

A combination of practices, typical of both greenhouse and field cultivation, were applied to the hybrid high tunnel system. For example, the apical meristems of the high tunnel plants were pinched to encourage the formation of two main leaders. A trellis system comprised of vertical strings hanging from horizontal tension cables extending across the width of the high tunnel structure was used. Tomato vines were attached to the strings with plastic plant clips, approximately every $25.4 \mathrm{~cm}$ (Hydro-Gardens Inc., Colorado Springs, CO). Vines were not topped and grew up to $2.4 \mathrm{~m}$ in height. Lower leaves were pruned to retain "one leaf below the first fruit cluster" and suckers were removed on a weekly basis to steer growth toward the main leaders and encourage fruit production.

The high tunnel side drop-down curtain system was operated manually in 2007 and with automatic mechanized controllers in 2008. In the beginning of the growing season, sidewall curtains were lowered (opened) when ambient air temperatures inside the tunnels exceeded $18{ }^{\circ} \mathrm{C}$ during the daytime and were closed in the evening. As the season progressed, the sidewall curtains were kept open when both day and nighttime temperatures were consistently above $13{ }^{\circ} \mathrm{C}$. The controller opened the curtains incrementally based on the change in temperature after 5 min of idle time. At the end of each season, the high tunnels were sealed for a solarization period of 3 weeks during late August to September.
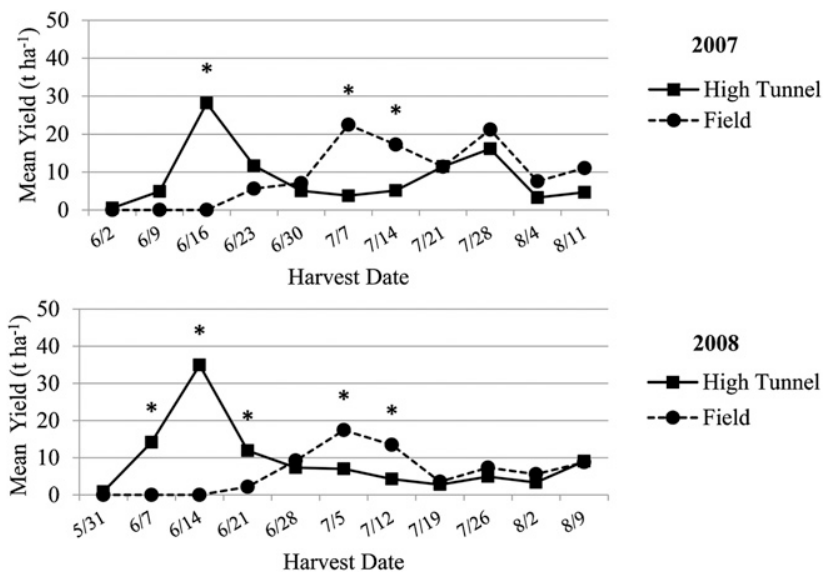

Fig. 2. Average weekly harvest yield overtime in the high tunnel and field system, 2007 and 2008. * Significant differences according to Tukey's mean separation test $(P \leq 0.05)$ for each harvest date. Each year was analyzed separately.

In the field system, the Florida stake-andweave training system was used. Metal posts ( $2.1 \mathrm{~m}$ height) were pounded $0.3 \mathrm{~m}$ into the ground between every other plant. Polyethylene string was wrapped around the posts, encompassing the plants and holding them upright. Plants were not pinched nor suckered. Leaf pruning was conducted up to the first horizontal string, which was $0.3 \mathrm{~m}$ above the ground. Field plants were subject to less pruning than the high tunnel plants, which resulted in a bushier growth form. Vines were not topped and grew up to $2.1 \mathrm{~m}$ in height. Solarization was not conducted in the field.

Pest management decisions were based on weekly scouting. Treatment decisions were based on established IPM thresholds for organic systems when available. In Spring 2007, the high tunnel system experienced a high population of potato aphids (Macrosiphum euphorbia). Two applications of insecticidal soap (M-Pede; Dow AgroSciences, Indianapolis, IN) took place followed by multiple releases of the aphid midge (Aphidoletes aphidimyza) and parasitic wasps (Aphidius ervi) (IPM Laboratories, Locke, NY). In both 2007 and 2008, two applications of Bacillus thurigiensis (Bt) were applied to each system targeting tomato hornworms (Manduca quinquemaculata), tomato fruitworms (Helicoverpa zea), and/or armyworms (Spodoptera sp.) (Xentari DF; Valent BioSciences Corp., Libertyville, IL; Dipel DF; Valent BioSciences Corp.). In 2008 , both systems experienced high populations of green stink bugs (Acrosternum hilare). The negative effects of spraying a broad-spectrum insecticide to reduce the population were judged to outweigh the benefits from the beneficial insect community present and hand-removal of stink bugs was the only control strategy used. In 2008 , an epidemic of GLS, caused by Stemphylium spp., occurred during the last month of production in the field system. Although cultural IPM strategies were used to reduce disease levels (i.e., staking, drip irrigation, removal of debris, scouting and eliminating nightshade weeds, etc.), no chemical or biological controls were used to reduce disease levels.

During the fall of 2006 and 2007, both systems received $2.24 \mathrm{t} \cdot \mathrm{ha}^{-1}$ of calcitic limestone $\left(\mathrm{CaCO}_{3}\right)$ in accordance with soil test recommendations. A combination of pre- and post-planting fertilizer contributed a total of $112 \mathrm{~kg} \mathrm{~N} / \mathrm{ha}$ to both systems each year, 2 weeks before transplanting seedlings. In 2007, the fertilizer application included 22 $\mathrm{t} \cdot \mathrm{ha}^{-1}$ of compost [Leprechaun NOP Compost $(2 \mathrm{~N}-0.9 \mathrm{P}-1.7 \mathrm{~K})$; McGill Environmental Systems, Harrells, NC] and $102 \mathrm{~kg} \cdot \mathrm{ha}^{-1}$ of 
Table 3. Comparison of mean tomato yield in high tunnel and field system, 2007 and 2008.

\begin{tabular}{|c|c|c|c|c|c|c|c|c|c|c|}
\hline \multirow[b]{2}{*}{$\mathrm{Yr}$} & \multirow[b]{2}{*}{ System } & \multicolumn{2}{|c|}{ Total yield } & \multirow{2}{*}{$\begin{array}{c}\text { Percent } \\
\text { marketable }\end{array}$} & \multicolumn{3}{|c|}{ Marketable yield } & \multicolumn{3}{|c|}{ Non-Marketable yield } \\
\hline & & $\mathrm{Wt}\left(\mathrm{t} \cdot \mathrm{ha}^{-1}\right)$ & Number $\left(10^{3} / \mathrm{ha}\right)$ & & $\mathrm{Wt}\left(\mathrm{t} \cdot \mathrm{ha}^{-1}\right)$ & Number $\left(10^{3} / \mathrm{ha}\right)$ & Avg size $(\mathrm{kg})$ & $\mathrm{Wt}\left(\mathrm{t} \cdot \mathrm{ha}^{-1}\right)$ & Number $\left(10^{3} / \mathrm{ha}\right)$ & Avg size $(\mathrm{kg})$ \\
\hline \multirow[t]{2}{*}{$\overline{2007^{z}}$} & High tunnel & $94.69 \mathrm{a}^{\mathrm{y}}$ & $413 \mathrm{a}$ & $36 \mathrm{~b}$ & $34.03 \mathrm{~b}$ & $162 \mathrm{a}$ & $0.22 \mathrm{a}$ & $60.65 \mathrm{a}$ & $250 \mathrm{a}$ & $0.21 \mathrm{a}$ \\
\hline & Field & $103.57 \mathrm{a}$ & $350 \mathrm{a}$ & $65 \mathrm{a}$ & $67.08 \mathrm{a}$ & $218 \mathrm{a}$ & $0.26 \mathrm{a}$ & $36.50 \mathrm{~b}$ & $132 \mathrm{~b}$ & $0.20 \mathrm{a}$ \\
\hline \multirow[t]{2}{*}{2008} & High tunnel & $100.64 \mathrm{a}$ & $464 \mathrm{a}$ & $69 \mathrm{a}$ & $69.64 \mathrm{a}$ & $312 \mathrm{a}$ & $0.20 \mathrm{a}$ & $31.00 \mathrm{a}$ & $152 \mathrm{a}$ & $0.20 \mathrm{a}$ \\
\hline & Field & $67.45 \mathrm{~b}$ & $287 \mathrm{~b}$ & $47 \mathrm{~b}$ & $31.49 \mathrm{~b}$ & $123 \mathrm{~b}$ & $0.17 \mathrm{~b}$ & $35.96 \mathrm{a}$ & $164 \mathrm{a}$ & $0.17 \mathrm{a}$ \\
\hline
\end{tabular}

${ }^{\mathrm{z} E a c h}$ year was analyzed separately.

${ }^{\mathrm{y}}$ Values followed by the same letter are not significantly different within a column according to Tukey's mean separation test $(P \leq 0.05)$.

feathermeal (Nutrimax “Super” Natural Organic Fertilizer (12N-0.4P-0K); Nutrimax Inc., Greensboro, NC). These applications were estimated to supply $99 \mathrm{~kg} \cdot \mathrm{ha}^{-1}$ of crop-available nitrogen $(\mathrm{N})$ (Table 1). The remaining balance $13 \mathrm{~kg} \mathrm{~N} / \mathrm{ha}$ was delivered to plants by a series of soluble fertilizer solution applications [Phytamin 801 (6N-0.4P-0.8K); California Organic Fertilizers, Inc., Fresno, CA] during the "first bloom to early harvest" growth stages (Heuvelink, 2005; Holmes and Kemble, 2007).

A winter cover crop comprised of $33.6 \mathrm{~kg} \cdot \mathrm{ha}^{-1}$ hairy vetch (Vicia villosa) and $50.4 \mathrm{~kg} \cdot \mathrm{ha}^{-1}$ winter rye (Secale cereale) was planted in both the high tunnel and field systems between the 2007 and 2008 growing seasons. A weekly determination was made of irrigation needs for the cover crops and water provided through overhead sprinklers. Aboveground biomass was sampled in the spring just before mowing. Cover crops were incorporated into the soil $28 \mathrm{~d}$ before transplanting seedlings in each system using a tractor-mounted rotary tiller.

Cover crop biomass was $43 \%$ greater in the high tunnel system compared with the field crop (Table 1). In the high tunnels, the cover crop was estimated to contribute $93 \mathrm{~kg}$ $\mathrm{N} /$ ha compared with only $53 \mathrm{~kg} \mathrm{~N} / \mathrm{ha}$ in the field. To equilibrate the pre-plant $\mathrm{N}$ input level (93 kg N/ha) across the two systems, $58.9 \mathrm{~kg} \cdot \mathrm{ha}^{-1}$ of feathermeal (41 kg N/ha) was applied to the field only (Table 1). In 2008, 19 $\mathrm{kg} \mathrm{N} /$ ha was delivered to plants by a series of soluble fertilizer solution applications [Phytamin 801 (6N-0.4P-0.8K); California Organic Fertilizers, Inc.] during the "first bloom to early harvest" growth stages (Heuvelink, 2005; Holmes and Kemble, 2007). Additional potassium was applied equivalently across systems during both years as recommended by soil and leaf tissue analysis (Table 2). Plant tissue samples were taken periodically during the growing season. Analysis indicated that an adequate supply of nutrients was provided to the crop throughout the season (data not shown).

Sampling protocols. Harvests were conducted twice per week from 27 May to 11 Aug. in 2007 and 25 May to 9 Aug. in 2008. Tomatoes were picked from the "pink to red" stages classified according to the USDA maturity standards (7 CFR § 51.1904) and sorted into marketable and non-marketable categories. Qualitative judgments relating to marketable and non-marketable fruit were based on observations from regional direct sales outlets for organic heirloom tomatoes.
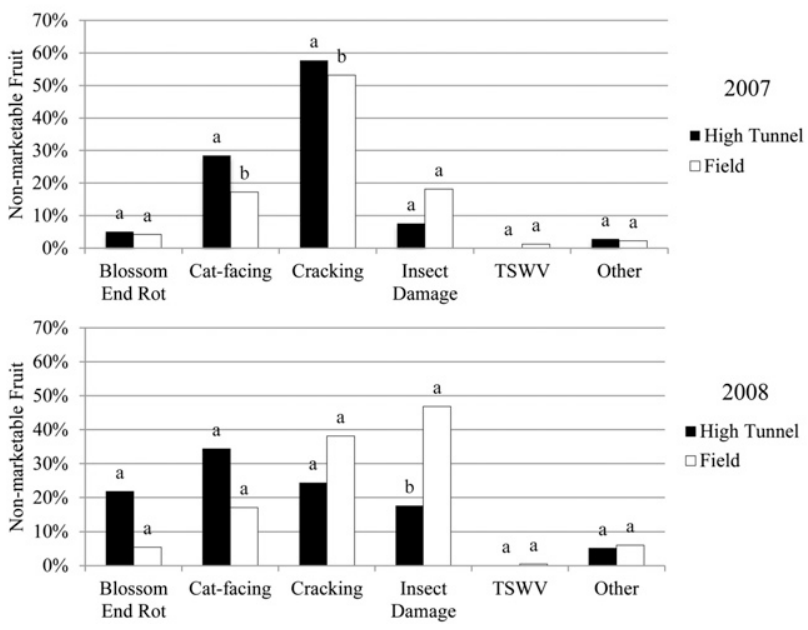

Fig. 3. Breakdown of non-marketable fruit damage in the high tunnel and field system, 2007 and 2008. Bars within the same category are not significantly different from each other if marked with the same letter according to Tukey's mean separation test $(P \leq 0.05)$. Each year was analyzed separately. Individual fruits were counted as having multiple disorders if more than one was present.

Non-marketable fruit was sorted into different categories based on types of defect including: cat-facing, blossom end rot, insect damage, fruit cracking, TSWV, and "other." The number of individual tomatoes as well as the total weight of fruit for each category was recorded during evaluations.

Assessments of foliar and soilborne diseases [i.e., TSWV (Tospovirus), GLS (Stemphylium spp.), and Early Blight (Alternaria spp.)] were conducted regularly. Disease ratings were carried out for each replicated plot within the high tunnel and field system. Plants that were diagnosed with TSWV during the first 4 weeks of production were replaced with non-infected transplants. In 2007, TSWV incidence was recorded weekly as number of plants per plot infected with TSWV. In 2008, the percentage of leaf area damage (\%LAD) caused by GLS was recorded twice every week. Plant roots were examined at the end of the growing season to identify the presence of root-infecting pathogens such as root-knot nematodes (Meloidogyne spp.), Ralstonia solanacearum, Fusarium oxysporum f.sp. lycopersici, and Sclerotium rolfsii. No symptoms from rootinfecting pathogens were evident throughout the study.

A variety of microclimatic measurements were recorded by automatic data loggers (HOBO Micro Station \#H21-002 Data Logger; Onset Computer Corp., Bourne, MA) located within each replicated plot, $\approx 1.85 \mathrm{~m}$ from the perimeter of the high tunnel and field plots. Air temperature sensors (\#S-THA-M002) were housed within protective plastic radiation shields $\approx 1 \mathrm{~m}$ aboveground. Soil temperature was measured belowground at a depth of $10 \mathrm{~cm}$ (\#S-TMB-M002). Soil moisture probes measured volumetric water content (\#S-SMAM005). All measurements were recorded every $15 \mathrm{~min}$ and hourly or daily means were calculated from these data. Precipitation data and a 7-year average air temperature (2003 to 2010) were supplied by the North Carolina State Climate Office weather station located $\approx 1.6 \mathrm{~km}$ from the project site (Cherry Research Station).

Statistical analysis. The data analysis for fruit yield, microclimate, GDD, and TSWV disease incidence was generated using a repeated measures analysis (Proc MIXED, SAS 9.2; SAS Institute, Cary, NC). Within each year, the design was a randomized block, having block and experimental unit variances, and with multiple measurements being made over time within each (block, treatment) combination. Date was added to the statistical model to measure fixed time effects. A control for autocorrelation showed none, resulting in a split plot structure with the whole plots in blocks and the split plot treatment being time. Means for significant effects and their interactions were compared using Tukey's honestly significant different test when $P<0.05$ (Proc LSMEANS, SAS 9.2; SAS Institute).

Biweekly harvest data were combined to provide weekly averages over the course of 
11 weeks for both systems. The T50 was defined as the number of days between transplanting and when $50 \%$ of the total fruit was harvested. GDDs were calculated using a base temperature of $10^{\circ} \mathrm{C}(\mathrm{McMaster}$ and Wilhelm, 1997). The TSWV data (number of infected plants per plot) from 2007 were used to determine the block frequency of TSWV. The frequency of disease incidence in each block was assigned one of the following bins: $0 \%$, $10 \%$ to $19 \%, 20 \%$ to $29 \%, 30 \%$ to $39 \%$, or greater than $40 \%$ incidence.

\section{Results}

The high tunnel harvest began $\approx 3$ weeks earlier than the field system across both years (Fig. 2). Peak harvest occurred between the first and third weeks of June for the high tunnel system and the first 2 weeks of July for the field system (Fig. 2). The total fruit yield (marketable + nonmarketable), both weight and number, was similar for the high tunnel and field system across both years $(P>0.05)$ but percent marketability was significantly different exhibiting a strong year $\times$ system interaction $(P<0.0001)$ (data not shown). As a result, each year was analyzed separately.

In 2007, the total yield (marketable + nonmarketable), both weight and number, was similar for high tunnel and field systems $(P>0.05)$; however, the marketable fruit weight was $45 \%$ less in the high tunnel $(P=$ $0.0230)$ than in the field system (Table 3 ). The average size of marketable fruit was statistically similar in both systems $(P=$ 0.1682) (Table 3). In 2008, the total yield (marketable + nonmarketable), both weight and number, was greater in the high tunnel compared with the field system $(P<0.01)$ (Table 3$)$. The marketable fruit weight was $55 \%$ greater in the high tunnel $(P<0.0071)$. The average size of marketable fruit was $15 \%$ greater in the high tunnel compared with the field system $(P<0.05)$. The amount of non-marketable fruit, both weight and number, was not different among the two systems during the second season $(P>0.05)$ (Table 3).

More than $50 \%$ of fruit damage was the result of cracking, cat-facing, and insect damage in 2007 (Fig. 3). The high tunnel system had a greater incidence of cracking and cat-facing compared with the field $(P<$ $0.05)$ and insect damage was not different in 2007 (Fig. 3). Cracking, cat-facing, and insect damage continued to be major impediments to fruit quality in 2008, although the incidence of cracking was reduced $\approx 20 \%$ and $\approx 10 \%$ in the high tunnel and field, respectively (Fig. 3). In 2008, insect damage in the high tunnel system accounted for $18 \%$ of the non-marketable fruit compared with $47 \%$ for the field system $(P=0.0098)$ (Fig. 3). Levels of fruit damage attributed to blossom end rot (BER), TSWV, and "other" categories were not different between systems either year.

Microclimate. Both growing seasons were warmer than the recent regional average (2003 to 2010) (Table 4). The high tunnel had

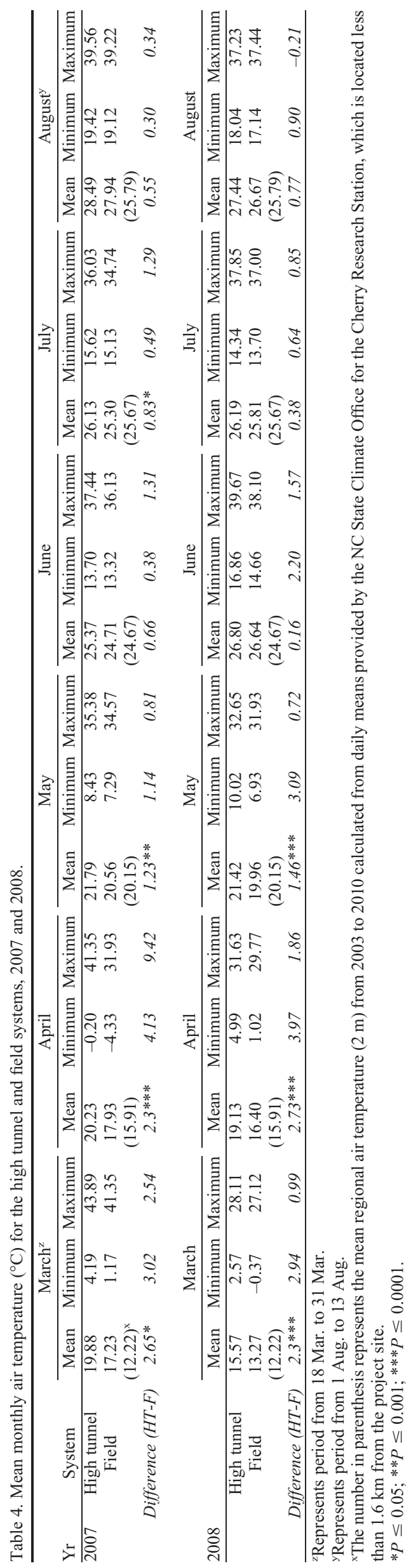


greater mean air temperatures (Table 4 ) and ${ }^{\circ}$ GDD (Fig. 4) compared with the field from mid-March through May across both years, whereas differences were generally not significant from June through mid-August. An average of $\approx 90$ to $95 \mathrm{~d}$ passed and 1100 ${ }^{\circ} \mathrm{GDD}$ accumulated before the T50 was reached in the high tunnel and field systems (Table 5). The high tunnel system accumulated $300{ }^{\circ} \mathrm{GDD}$ more than the field system over the entire season (Table 5). Soil moisture levels were not significantly different between growing systems (data not shown).

Each spring there were frost events that threatened to damage the high tunnel crop in either March or early April. The field was not threatened because it was not planted until mid-April. For example, from 21 to 26 Mar. 2008 , temperatures in the high tunnel dropped as low as $2.5^{\circ} \mathrm{C}$ compared with $0{ }^{\circ} \mathrm{C}$ in the field (Fig. 5). Although the difference between minimum daily temperatures of the high tunnel and field was slight, the high tunnel plants did not show any signs of external cold damage. An annual 3-week solarization treatment, applied from late August through midSeptember, in the high tunnel system resulted in average soil temperatures of 34 and $32{ }^{\circ} \mathrm{C}$ in 2007 and 2008, respectively (data not shown). The average high tunnel soil temperatures were 5 to $7{ }^{\circ} \mathrm{C}$ greater than the non-solarized field soil at a depth of $10 \mathrm{~cm}$ (data not shown).

Disease incidence. In 2007, there was low disease pressure from common fungal leaf pathogens (e.g., Stemphylium spp. and Alternaria solani, etc.) probably as a result of infrequent precipitation, yet the incidence of TSWV was particularly high throughout the region. TSWV incidence ranged from $0 \%$ to $33 \%$ within our high tunnel and field systems (Fig. 6). Overall, the high tunnel exhibited less frequent TSWV compared with the field (Fig. 6, $P<0.05$ ). In 2008, TSWV incidence was very low (less than $1 \%$ overall incidence) across both systems (data not shown).

In 2008, an epidemic of GLS, caused by Stemphylium spp., led to rapid foliar damage and subsequent defoliation of the tomato crop in the field (Fig. 7). On 14 July, the mean $\%$ LAD from GLS was 1\% within the high tunnel and $7.5 \%$ in the field. Two weeks later, the mean $\%$ LAD was $24 \%$ in the field and was $52 \%$ on termination of the trial. Conversely, the mean \%LAD from GLS inside the high tunnel remained at trace levels throughout the course of the season and was $5 \%$ on termination of the experiment (Fig. 7).

\section{Discussion and Conclusions}

The ability of high tunnels to advance crop harvests has been shown for various temperate regions. Our data suggest that in a humid, subtropical climate such as eastern North Carolina, high tunnels can advance a summer tomato crop by 3 to 4 weeks. The protection from low temperatures, earlier accumulation of GDD, and greater ability to manage the high tunnel environment allows growers to supply tomatoes for early markets. Many growers report that early tomatoes can obtain premium prices as well as help with developing customer loyalty, both of which can result in greater profits.

The high tunnel and field systems were both capable of producing $\approx 100 \mathrm{t} \cdot \mathrm{ha}^{-1}$ of organic, heirloom tomatoes; however, only the high tunnel demonstrated this level of productivity for two consecutive seasons. This suggests reduced yield variability with high tunnel systems compared with the field. Overall, the high tunnel system produced an average of $8.2 \mathrm{~kg}$ of fruit per plant compared with $7.2 \mathrm{~kg}$ per plant in the field system. These yields were similar to other reports for 'Cherokee Purple' production in the Southeast from $5.7 \mathrm{~kg} / \mathrm{plant}$ in the field to $13.0 \mathrm{~kg} /$ plant under a high tunnel (Rivard et al., 2010; Vavrina et al., 2003).

The ability of the high tunnels to accrue more daytime heat resulted in the accumulation of GDD at a faster rate than the field in the early growing season across both years (March to May). An average of 86 to $95 \mathrm{~d}$ after transplanting and $\approx 1100$ GDD was
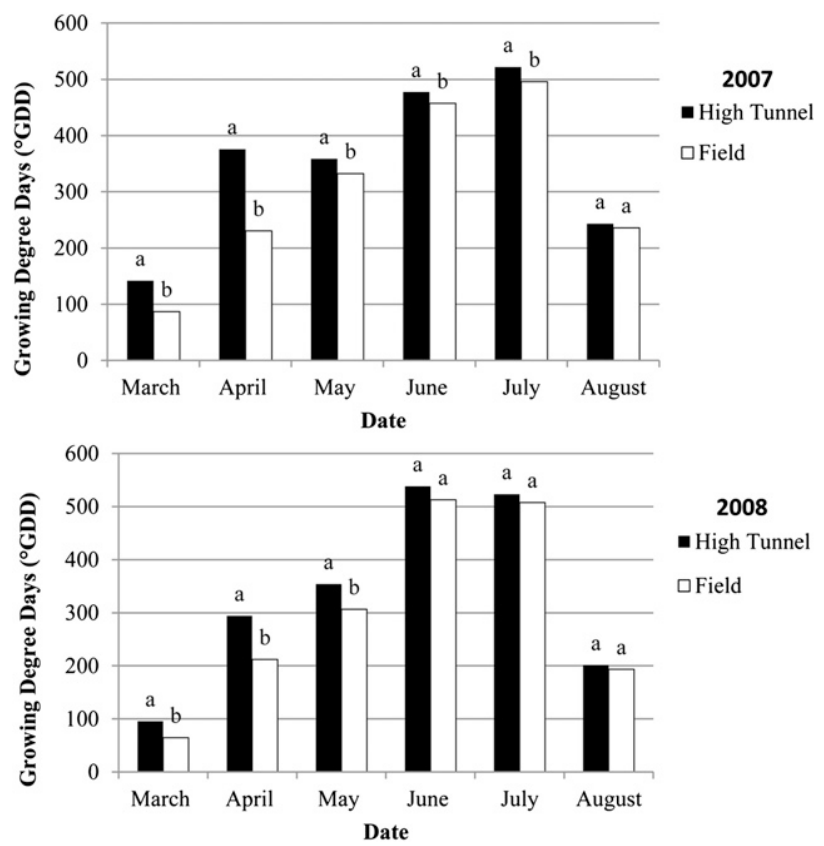

Fig. 4. Mean monthly ${ }^{\circ}$ GDD accumulated in the high tunnel and field system, 2007 and 2008. The months of March and August only include 20 to 31 Mar. and 1 to 11 Aug., respectively. All other months are complete. Bars within the same month are not significantly different from each other if marked with the same letter according to Tukey's mean separation test $(P \leq 0.05)$. Each year was analyzed separately. $\mathrm{GDD}=$ growing degree-days

Table 5. Growing degree-days (GDD) and the number of days between transplanting and $50 \%$ harvest (T50) for the high tunnel and field system, 2007 and 2008.

\begin{tabular}{|c|c|c|c|c|c|c|c|c|}
\hline \multirow{2}{*}{$\mathrm{Yr}$} & \multicolumn{2}{|c|}{$\begin{array}{l}\text { Transplant } \\
\text { date }\end{array}$} & \multicolumn{2}{|c|}{ T50 (d) $)^{\mathrm{z}}$} & \multicolumn{2}{|c|}{${ }^{\circ} \mathrm{GDD}$ to $\mathrm{T} 50^{\mathrm{y}}$} & \multicolumn{2}{|c|}{$\begin{array}{c}{ }^{\circ} \text { GDD for } \\
\text { entire season }\end{array}$} \\
\hline & High tunnel & Field & $\overline{\text { High tunnel }}$ & $\overline{\text { Field }}$ & High tunnel & $\overline{\text { Field }}$ & High tunnel & $\overline{\text { Field }}$ \\
\hline 2007 & 20 Mar. & 19 Apr. & 102 & 86 & 1342 & 1128 & 2170 & 1625 \\
\hline 008 & 18 Mar. & 17 Apr. & 88 & 86 & 973 & 1108 & 2008 & 16 \\
\hline
\end{tabular}

${ }^{2}$ T50 represents the number of days between transplanting and when $50 \%$ of fruit was harvested. ${ }^{y}$ Growing degree-days $\left({ }^{\circ} \mathrm{GDD}\right)$ until $50 \%$ of fruit was harvested.

${ }^{\mathrm{x}}$ Growing degree-days $\left({ }^{\circ} \mathrm{GDD}\right)$ from transplanting until end of growing season (high tunnel season was 4 weeks longer than the field system season both years).

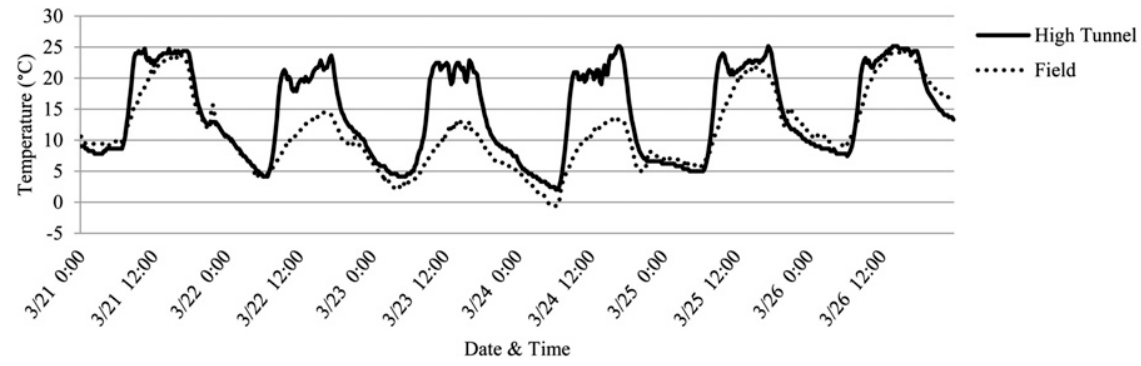

Fig. 5. Mean minimum air temperatures during a cold spell for the high tunnel and field system, 21 to 26 Mar. 2008. Measurements were taken every $15 \mathrm{~min}$. 
required to reach $\mathrm{T} 50$ with our indeterminate cultivar in both systems. Growers wanting to further optimize early-season production may choose tomato varieties with fewer days to maturity and/or more deterministic characteristics.

Although the high tunnel system gives the grower additional control over the microclimate compared with the field, it is not always possible to maintain optimum daytime ( 25 to $\left.30{ }^{\circ} \mathrm{C}\right)$ or nighttime temperatures $\left(\approx 20{ }^{\circ} \mathrm{C}\right)$ for crop growth. Increases in nighttime temperatures in the high tunnel compared with the field were modest as has been seen in other studies (Both et al., 2007; Giacomelli, 2009; Jett et al., 2004; Ogden and van Iersel, 2009; Waterer, 2003). On the coldest evenings, the difference of just a few degrees appeared to provide frost protection to the high tunnel transplants even when temperatures dropped below $0{ }^{\circ} \mathrm{C}$ in the field. The inflated double polyethylene film roof likely gave greater freeze protection compared with a single polyethylene film found on some high tunnel structures. In addition, residual soil heat absorbed during the day releases from the soil during the night increasing the air temperature (Baille et al., 2006). This absorption was maximized in our system with the addition of black polypropylene landscape fabric over the soil. Cloud cover on cold evenings may

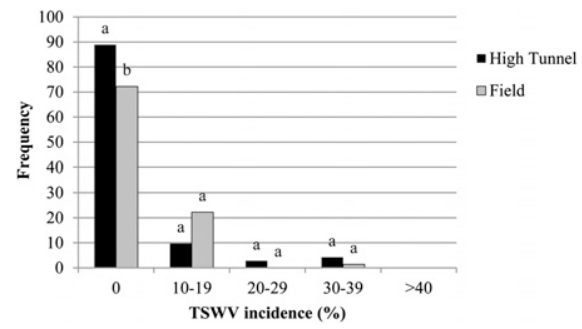

Fig. 6. Mean Tomato Spotted Wilt Virus (TSWV, Tospovirus) incidence for the high tunnel and field system, 2007. Bars within the same category are not significantly different from each other if marked with the same letter according to Tukey's mean separation test $(P \leq 0.05)$. also have reduced the rate of radiative cooling from the high tunnel (Ogden and van Iersel, 2009).

The popular 'Cherokee Purple' tomato variety appears to be very susceptible to a number of fruit defects. The percent marketability of the tomato crop fluctuated from $36 \%$ to $69 \%$ in the high tunnels and $47 \%$ to $65 \%$ in the field across the 2 study years. In 2007 , only $36 \%$ of the high tunnel fruit harvest was considered marketable; in 2008, this increased to $69 \%$. The difference in marketability across the years was primarily the result of a decrease in fruit cracking incidence. An organic farm in the same region achieved an average of $75 \%$ marketability with their 'Cherokee Purple' crop in 2007 and 2008 (Rivard et al., 2010). Multiple factors are thought to affect fruit cracking including: genetic susceptibility, fluctuations in plant water status and/or diurnal temperatures, rapid fruit growth, high humidity, and fruit subjected to high light intensity (Peet, 1992). Although the 'Cherokee Purple' variety appears to be susceptible to cracking, modifications to cultural management practices may help limit the level of damage. In 2008, slight modifications were made to our irrigation protocols including: more frequent yet shorter irrigation intervals and less frequent sucker pruning during the harvest period to provide more shade to developing fruit. One or a combination of these factors may be responsible for decreased fruit cracking during our second season. Picking fruit more frequently and/or at an earlier ripeness stage may also help decrease cracking incidence. In addition, the application of shadecloth to lower the light intensity and subsequent fruit surface temperature may help to decrease fruit cracking (Gent, 2007; Peet, 1992).

Cat-facing was another major factor that affected fruit quality. Scarring of the blossom end or misshapen fruit are characteristic of the damage. Cat-facing incidence is associated with exposure to low temperatures although there is no agreement on this threshold. Critical temperatures that may prevent complete pollination and normal flower development

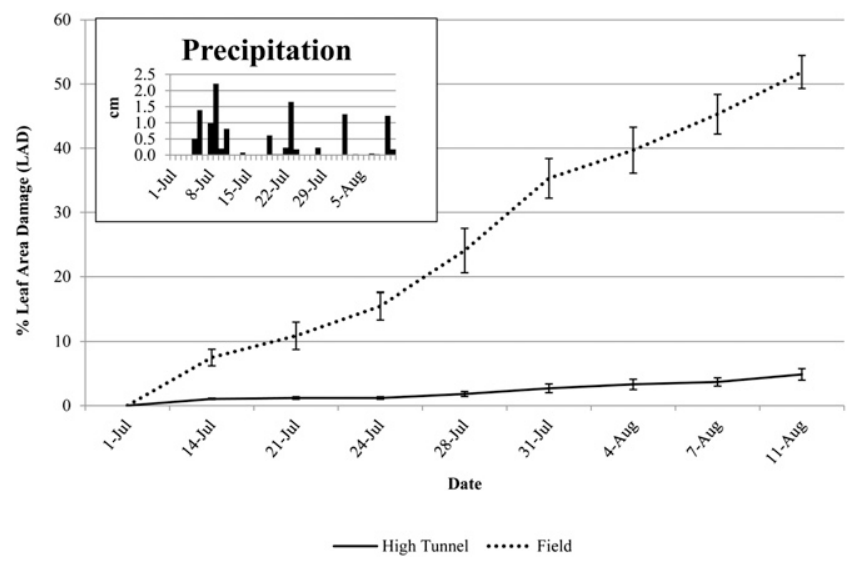

Fig. 7. Percentage of leaf area damage (\%LAD) caused by Gray Leaf Spot (Stephylium spp.) for the high tunnel and field system, 2008. Bars within the same category are not significantly different from each other if marked with the same letter according to Tukey's mean separation test $(P \leq 0.05)$. are reported to range from 10 to $12.8{ }^{\circ} \mathrm{C}$ (Jones, 2008; Saito and Ito, 1971). More frequent exposure to low temperatures during early growth may increase the incidence of cat-facing damage. In 2007, high tunnel plants were exposed to minimum daily temperatures below $12.8^{\circ} \mathrm{C}$ for a total of $32 \mathrm{~d}$ during their first 2 months of growth compared with $19 \mathrm{~d}$ in the field-planted system. In 2008, high tunnel plants were exposed to minimum daily temperatures below $12.8{ }^{\circ} \mathrm{C}$ for a total of $31 \mathrm{~d}$ compared with $21 \mathrm{~d}$ for the field system. Greater exposure of high tunnel plants to cold air temperatures in the early spring, as opposed to the later planted field system, may have led to greater cat-facing incidence. To decrease cat-facing incidence, growers may consider a delayed planting date, using supplemental heating in high tunnels during cold weather, covering plants or the tunnel structure with additional insulating fabrics, optimizing daytime heat storage, and/or using less susceptible varieties.

BER was the third most common physiological disorder, which occurred across both systems. Incidence of BER is attributed to a calcium deficiency in the fruit, correlated with root zone salinity, soil water stress, excessive $\mathrm{N}$ fertilization, and/or rapid fruit growth (Dorais and Papadopoulos, 2001; Saure, 2001). Lower BER incidence may be achievable with less susceptible varieties as well as modified cultural practices pertaining to irrigation, fertilization, pruning, and training.

Overall, pest types were similar in the high tunnel and field systems with few exceptions. The high tunnel system was subject to an aphid outbreak (Macrosiphum euphorbia) early in the first season. Because the high tunnel was primarily a closed system at this point, the outbreak was successfully controlled by a combination of organic pesticide applications and a series of predator releases. Previous studies in the region have reported variable insect and disease-induced losses depending on early or late planting dates (Kennedy et al., 1983). We found a similar composition of major pests (Lepidopteran sp. and Acrosternum hilare) across both system types, which had planting dates that were offset by 1 month but were physically in close proximity. Insect damage to fruit was significantly greater in the field during the 2008 compared with the 2007 season.

As a result of the lack of consistent disease pressure across multiple growing seasons, we were only able to capture 1 year of data each for TSWV and GLS. Although it is difficult to make firm conclusions, the data indicate that high tunnels help protect organic tomato crops from TSWV and GLS incidence. Others have predicted that high tunnels help to manage leaf-infecting pathogens by reducing leaf wetness (Xiao et al., 2001). In the case of GLS, we saw evidence to support this claim. The mechanism by which high tunnels protect crops from TSWV, which is transmitted by thrips, is unclear because the sidewalls were open for most of the season and requires further research to validate and explain the effect. 
Although both systems were planted with the same winter cover crop mixture between the 2007 and 2008 growing seasons, the shoot biomass in the high tunnels was $43 \%$ greater than the field. Therefore, additional pre-plant fertilizer was applied to the field to bring the pre-plant $\mathrm{N}$ levels up to match the high tunnel system. This action may have introduced greater variability between the growing systems in 2008 as a result of a difference in fertilizer decomposition rates, interactions with the soil microbial community, and/or influence on soil moisture levels and soil temperatures. However, it did demonstrate that increased cover crop growth under high tunnels can be a valuable management tool for producers. Cover crops can improve soil quality, contribute and recycle nutrients, and break pest disease cycles (Sustainable Agriculture Network, 2007).

Earlier harvests, cold temperature protection, and more consistent yields were the main advantages of high tunnel production in this study. The ability of the high tunnel as a closed system can also encourage the adoption of environmentally friendly practices to manage pests and improve soil quality such as beneficial insect releases, solarization, and extended-season cover cropping. Climate change models predict that the southeast region will experience more extreme weather events (i.e., greater frequency and intensity of droughts and hurricanes), increased rates of summer warming, and be subject to amplified levels of pests and diseases (Karl et al., 2009). High tunnel systems should be able to mitigate some of these factors by providing additional protection and management opportunities for wind, rain, pests, and temperature fluctuations as well as offering season extension possibilities.

\section{Literature Cited}

Agricultural Marketing Service. 2011. More than 1,000 new farmers markets recorded across country as USDA directory reveals 17 percent growth. USDA. 10 Aug. 2011. <http://www. ams.usda.gov>.

Baille, A., J.C. Lopez, S. Bonachela, M.M. GonzalezReal, and J.I. Montero. 2006. Night energy balance in a heated low-cost plastic greenhouse. Agr. For. Meteorol. 137:107-118.

Baldwin, K.R. and N. Creamer. 2006. Cover crops for organic farms. Center for Environmental Farming Systems. NC Coop. Ext AG-659:W-03.

Baldwin, K.R. and J. Greenfield. 2006. Composting on organic farms. Center for Environmental Farming Systems. NC Coop. Ext AG-659:w-01.

Blomgren, T. and T. Frisch. 2007. High tunnels: Using low-cost technology to increase yields, improve quality and extend the season. Univ. of VT Center for Sustainable Agr. 10 Feb. 2011. $<\mathrm{http}: / /$ www.uvm.edu/sustainableagriculture/ Documents/HighTunnels.pdf $>$.

Both, A.J., E. Reiss, J.F. Sudal, K.E. Holmstrom, C.A. Wyenandt, W.L. Kline, and S.A. Garrison. 2007. Evaluation of a manual energy curtain for tomato production in high tunnels. HortTechnology 17:467-472.
Calvin, L. and R. Cook. 2005. North American greenhouse tomatoes emerge as a major market force. Amber Waves, ERR-2. USDA/ERS. Washington, DC. 3:21-27.

Carey, E.E., L. Jett, W.J. Lamont, Jr., T.T. Nennici, M.D. Orzolek, and K.A. Williams. 2009. Horticultural crop production in high tunnels in the United States: A snapshot. HortTechnology 19:1.

Conner, D.S., K.B. Waldman, A.D. Montri, M.W. Hamm, and J.A. Biernbaum. 2010. Hoophouse contributions to economic viability: Nine Michigan case studies. HortTechnology 20:877884.

Dorais, M. and T. Papadopoulos. 2001. Greenhouse tomato fruit quality. Hort. Rev. 26:239319.

Fernandez-Cornejo, J., D. Newton, and R. Penn. 1994. Organic vegetable growers surveyed in 1994. USDA/ERS, Washington, DC. AH-705.

Gent, M.P.N. 2007. Effect of degree and duration of shade on quality of greenhouse tomato. HortScience 42:514-520.

Giacomelli, G.A. 2009. Engineering principles impacting high-tunnel environments. HortTechnology 19:30-33.

Hanson, E., M. von Weihel, A.C. Schilder, A.M. Chanon, and J.C. Schreerens. 2011. High tunnel and open field production of floricane- and primocane-fruiting raspberry cultivars. HortTechnology 21:412-418.

Heuvelink,, E. (ed.). 2005. Tomatoes. Crop production science in horticulture, 13. CABI Publishing, Wallingford, UK.

Holmes, G.J. and J.M. Kemble (eds.). 2007. Vegetable crop handbook for southeastern United States. SEVEW Group, Vance Publishing Corp. Lincolnshire, IL. p. 82-86.

Jett, L., D. Coltrain, J. Chism, J. Quinn, and A. Read. 2004. High tunnel tomato production. Univ. of Missouri Ext. \#M170.

Jones, J.B., Jr. 2008. Tomato plant culture. CRC Press, Boca Raton, FL.

Jordan, J.A. 2007. The heirloom tomato as cultural object: Investigating taste and space. Sociol. Ruralis 47:1.

Kadir, S., E. Carey, and S. Ennahli. 2006. Influence of high tunnel and field conditions on strawberry growth and development. HortScience 41:329-335

Karl, T.R., J.M. Melillo, and T.C. Peterson (eds.). 2009. Global climate change impacts in the U.S. Cambridge University Press, New York, NY.

Kennedy, G.G., L.R. Romanow, S.F. Jenkins, and D.C. Sanders. 1983. Insects and diseases damaging tomato fruits in the coastal plain of North Carolina. J. Econ. Entomol. 76:168-173.

Knewston, S.J.B., R.J. Janke, M.B. Kirkham, K.A. Williams, and E.E. Carey. 2010. Trends in soil quality under high tunnels. HortScience 45: 1534-1538.

Lamont, W.J., Jr. 2009. Overview of the use of high tunnels worldwide. HortTechnology 19:1.

Lucier, G. 2009. Vegetables \& melons: Tomatoes. USDA Briefing Rooms from the ERS. Washington, DC. 6 June 2010. <http://www.ers. usda.gov/Briefing/Vegetables/tomatoes.htm>.

Lyson, T.A., G.W. Gillespie, Jr., and D. Hilchey. 1995. Farmers markets and the local community: Bridging the formal and informal economy. Amer. J. Altern. 10:108-113.

McMaster, G.S. and W.W. Wilhelm. 1997. Growing degree-days: One equation, two interpretations. Agr. For. Meteorol. 87:291-300.
Ogden, A.B. and M.W. van Iersel. 2009. Southern highbush blueberry production in high tunnels: Temperatures, development, yield, and fruit quality during the establishment years. HortScience 44:1850-1856.

Organic Trade Association. 2011. Organic Trade Association's 2011 Organic Industry Survey. Nutrition Business J.

Peet, M.M. 1992. Fruit cracking in tomato. HortTechnology 2:216-223.

Rivard, C.L. and F.J. Louws. 2008. Grafting to manage soilborne diseases in heirloom tomato production. HortScience 43:2104-2111.

Rivard, C.L., S. O'Connell, M.M. Peet, and F.J. Louws. 2010. Grafting tomato with interspecific rootstock to manage diseases caused by Sclerotium rolfsii and southern root-knot nematode. Plant Dis. 94:1015-1021.

Rowley, D., B.L. Black, D. Drost, and D. Feuz. 2010. Early-season extension using Junebearing 'Chandler' strawberry in high-elevation high tunnels. HortScience 45:1464-1469.

Saito, T. and H. Ito. 1971. Studies on the growth and fruiting in the tomato. XI. Effect of temperature on the development of flower, especially that of the ovary and its locule. J. Jpn. Soc. Hort. Sci. 40:128-138.

Salame-Donoso, T.P., M. Bielinski, M. Santos, C.K. Chandler, and S.A. Sargent. 2010. Effect of high tunnels on the growth, yields, and soluble solids of strawberry cultivars in Florida. Intl. J. Fruit Sci. 10:249-263.

Saure, M.C. 2001. Blosson-end rot of tomato (Lycopersicon esculentum Mill.): A calciumor a stress-related disorder? Sci. Hort. 90:193208.

Stevens-Garmon, J., C.L. Huang, and L. Biing-Hwan. 2007. Organic demand: A profile of consumers in the fresh produce market. Choices. Amer. Agr. Econ. Assoc. 22:109-115.

Sustainable Agriculture Network. 2007. Managing cover crops profitably. $3^{\text {rd }}$ Ed. Clark, A. (ed.). Sustainable Agr. Network, Beltsville, MD.

Vavrina, C.S., K. Armbresterm, and M. Pena. 2003. Growing heirloom tomato varieties in southwest Florida. Fact sheet HS921. FL Coop. Ext. Ser., Inst. Food and Agr. Sci., Univ. of Florida.

Waterer, D. 2003. Yields and economics of high tunnels for production of warm-season vegetable crops. HortTechnology 13:2.

Wells, O.S. 1991. Guidelines for using high tunnels for tomato production. Univ. of New Hampshire Coop. Ext. Publ.

Wilson, C. and G. Morren. 1990. Systems approaches for improvement in agriculture and natural resource management. MacMillan, New York, NY.

Wittwer, S.H. and N. Castilla. 1995. Protected cultivation of horticultural crops worldwide. HortTechnology 5:6-23.

Xiao, C.L., C.K. Chandler, J.F. Price, J.R. Duval, J.C. Mertely, and D.E. Legard. 2001. Comparison of epidemics of Botrytis fruit rot and powdery mildew of strawberry in large plastic tunnel and field production systems. Plant Dis. 85:901-909.

Yao, S. and C.J. Rosen. 2011. Primocane-fruiting raspberry production in high tunnels in a cold region of the upper midwestern United States. HortTechnology 21:429-434.

Zublena, J.P., J.C. Barker, and T.A. Carter. 1993. SoilFacts: Poultry manure as a fertilizer source. North Carolina Coop. Ext. \#AG-439-5. 